\title{
On the Link between Japanese ODA and FDI in China : A Microeconomic Evaluation Using Conditional Logit Analysis
}

\author{
Séverine BLAISE \\ CEFI-CNRS, Faculté des Sciences Economiques, Université de la Méditerranée \\ CEREFI, Faculté d'Economie Appliquée, Université d'Aix-Marseille III \\ 15-19 Allée Claude Forbin 13627 Aix-en-Provence, France \\ E-mail :severine_blaise@hotmail.com
}

\begin{abstract}
This paper investigates the effectiveness of Japan's official development assistance in promoting foreign direct investments inflows in the case of the People's Republic of China. Conditional logit analysis using province level statistics from 1980 to 1999, shows that Japanese aid flows did have a significant positive impact on private investors location choice even though other profit-maximizing factors such as the level of economic activity had a leading spillover effect. In a context of growing scarcity of aid, we conclude by asserting the importance of a complementary process in which foreign aid is aimed at enhancing the development of infrastructures, acting as a pre-requisite for future direct investments. Finally, Japan providing an interesting case study, we stress the need for a better cooperation between public and private sectors in development assistance programs.
\end{abstract}




\section{Introduction}

Even since Japan emerged as the largest donor of official development assistance (ODA) in volume, its motives and practice for giving aid got more and more attention. Heavily criticized from both inside and outside Japan, Japanese aid policy has long been depicted as 'mercantilist' and routinely accused of 'unfair aid practices'. The concentration of aid flows on Asian countries, the emphasis on capital projects for economic infrastructures, the strong involvement of Japan's private sector in development co-operation are the key features of Japanese aid program that have been under harsh scrutiny (Ensign, 1992).

The purpose of this study is to verify whether Japanese aid leans on a better economic rationalization of aid programs by evaluating its effectiveness in promoting foreign direct investments (FDI). In the case of the People's Republic of China (China hereafter) we investigate the link between Japanese public and private sector in development cooperation. Indeed, the underlying idea is that ODA projects act as a prerequisite for future private investment, notably through the development of infrastructures in recipient countries.

China is one of the Asian countries that had the most intense relationship with Japan for cultural, historical and strategic reasons. Even though Japan has always been distrustful of China, after World War II the 1972 Sino-Japanese rapprochement and the 1978 Sino-Japanese Peace and Friendship Treaty laid foundations for the rapid development of bilateral relations. China began its economic reform and opendoor policy and for the first time showed a willingness to accept foreign aid. As a consequence, Japanese aid program to China began much later than in other Asian countries. Even though, from 1979 Japanese aid grew substantially : from 1982 to 1986 China was the largest recipient of Japanese aid and ever since it has been the 
second largest recipient next to Indonesia ${ }^{1}$. In the mean time, China has been economically very important to Japan : the enormous potential of its market has led many Japanese companies to invest in China, and the two countries rapidly became major trade partners.

The next section presents an econometric analysis aimed at verifying the role of ODA projects in the location decision of Japanese private investors using conditional logit analysis. The literature on the economic impact of FDI is vast and we will not discuss this issue here. However, following Ichikawa (1991), one could assert that FDI, unlike portfolio investment, promotes the dissemination of valuable knowledge and entrepreneurship in the form of research and development, production technology, marketing skills, managerial expertise, and so on. That is, direct investment is a vehicle for the dissemination of these inputs and services, not simply a provider of finance. Thus, direct investment - particularly in manufacturing - is more likely than portfolio investment to promote economic growth. Therefore, one could expect ODA to contribute substantially to the economic growth of a recipient country not only through its direct impact, but also indirectly by promoting the inflows of FDI.

\section{Methodology}

A number of works was carried out on the relationship between ODA and FDI in the case of Japan. Nevertheless, the causal relation that has been evaluated is rather the opposite. That is, to assert the impact of FDI as a determinant of ODA flows ${ }^{2}$. As far as we know, few studies (with contrasted results) have considered the possibility that ODA act as a prerequisite for future Japanese $\mathrm{FDI}^{3}$. These studies suffer a number of shortcomings ranging from misspecification for some, to invalid 
estimation methodology for others. Yet, their common limitation lies in their restriction to macroeconomic framework. As pointed out by Mosley, while at the microeconomic level evaluation of aid effectiveness brings generally satisfactory results, macroeconomic analyses remain quite ambiguous (the so-called "MacroMicro paradox"). Moreover, in the case of large countries such as China, because there is a great disparities in the geographical distribution of those financial flows, it does not seem very relevant to consider the country as a whole. Consequently, we would rather perform a microeconomic evaluation of the relationship between Japanese ODA and FDI, using province level statistics of the Chinese economy as well as detailed data on Japanese affiliates activity. This evaluation is carried out on the period 1980-1999. Statistics for ODA are issued from the Japan Bank for International Cooperation (JBIC) online database for loan aid, and "ODA Annual Report" of the Ministry of Foreign Affairs for grant aid. We refer to ODA as the sum of loan and grant aid, setting aside technical cooperation. Those statistics have been classified by province (calculation from the author). As far as FDI are concerned, we use Toyo Keizai "Overseas Japanese Companies Data" from 1990 and 1999 editions which also allow us to have a classification by Chinese province of Japanese affiliates activities. Statistics for each Chinese province are compiled from "China Statistical Yearbook" published by China Statistical Publishing House, various volumes. This process will allow us to have a more precise perception of the 'spillover effect' of foreign aid. 


\section{Model}

The location decision of Japanese investor in China is analysed by means of a conditional logistic regression in which we introduce ODA along with other profitmaximizing factors.

Conditional logit model has been widely used in previous empirical studies of location choice. For example Head, Ries \& Swenson (1995) examined the agglomeration benefit and location choice of Japanese manufacturing in the United States. Fukao \& Yue (1997), analyzed the determinants of FDI by Japanese electronic firms. Belberdos \& Carree (2002) also examined the location of Japanese Investment in China, focusing on agglomeration effects, Keiretsu and firm heterogeneity. Urata \& Kawai (1999) studied the determinants of the location of FDI by Japanese small and medium-sized enterprises ${ }^{4}$. The conditional logit model was first developed in economic analysis by Mc Fadden (1973).

The purpose of this study is to verify if, in a given province, the amount of Japanese aid has an impact on the location choice of Japanese private investors, for instance through the development of infrastructure. To model the location of Japanese FDI in China, we assume that Japanese firms undertake FDI in a province where they can maximize their profit after evaluating relevant characteristics of alternative locations. By assuming that the firm has a production function of CobbDouglas form, let us describe the profit $(\pi)$ of firm $i$ obtained from undertaking FDI in province $\mathrm{j}$ as Equation (1).

$$
\pi_{i j}=a_{0} X_{1 j}^{a 1} \ldots a_{m} X_{m j}^{a m} \cdot e^{\mu_{i j}}
$$

where $a_{0}, \ldots, a_{m}$ are unknown parameters, $X_{s j}(s=1, \ldots, m)$ are variables describing the characteristics of the province $\mathrm{j}(\mathrm{j}=1, \ldots, \mathrm{n})$, and $\mu_{\mathrm{ij}}$ is a random 
disturbance term capturing province- and investment specific-heterogeneity in total factor productivity.

Given profit equation (1), if and only if $\mu_{\mathrm{ij}}$ is distributed as Type I extreme value (independent random variable) according to the Weibull distribution, then the probability that province $\mathrm{j}$ will yield investor $\mathrm{i}$ the highest profit among all the provinces is given by the logit expression (Equation 2) (McFadden, 1973).

$$
P_{i j}=\frac{\exp \left(\sum_{s=1}^{m} a_{s} \ln X_{s j}\right)}{\sum_{j=1}^{n} \exp \left(\sum_{s=1}^{m} a_{s} \ln X_{s j}\right)}
$$

We express the number of FDI selections made by Japanese firm $i$ in the province $\mathrm{j}$ as $\mathrm{W}_{\mathrm{ij}}(\mathrm{j}=1, \ldots, \mathrm{n})$. This dependent variable takes the value 1 if the province is selected by the investor and 0 otherwise. Finally, we obtain the probability of observing such FDI pattern as Equation (3).

$$
L=\prod_{i} \prod_{j=1}^{n} P_{i j}^{W_{i j}}
$$

The parameter $\left(\mathrm{a}_{0}, \ldots, \mathrm{a}_{\mathrm{m}}\right)$, which indicate the characteristics of potential host provinces to Japanese FDI, are estimated by the maximum likelihood method, which maximizes the likelihood function (Equation 3).

In other respects, as pointed out in previous studies the location choice criteria may vary across different sectors. Therefore, the estimation is carried out in both manufacturing and non-manufacturing sectors. The following variables enter into consideration as independent variables:

- Agglomeration effect: economic activities of existing Japanese firms in one province that generate positive externalities for nearby firm engaged in similar activity. This is measured by the number of existing Japanese affiliates before the 
venture began operation (JAmc and JAnmc, respectively for manufacturing and non-manufacturing sector). Note that we use this number plus one in order to be able to use the log of the variable.

- Level of economic activity: we control for economic size of the provinces by including the per capita GDP (GDPc). Indeed, the larger the economic size of a region, the more likely that it will receive foreign investments.

- Production cost: labor cost is recognized as one of the most important factors. It is given by the average wage level of workers (Wage), which is expected to discourage investment especially in the case of manufacturing location.

- Infrastructure: a well developed transportation infrastructure reduces the costs of importing inputs and exporting or distributing output as well as a good communication infrastructure facilitates and reduces the cost of communication of affiliates. Consequently, we expect infrastructure indicator to have a positive impact on the location decision of private investors.

We introduce the dummy Coast $(\mathrm{C})$, which takes the value 1 if the region is located on the coast side and 0 otherwise, as well as the distance from Japan (DIST).

We also include a measure of the quality of telecommunication infrastructure : the number of long-distance telephone lines (Telecom). Finally, we introduce the cumulative amount of Japanese aid (ODAc), which is also supposed to reinforce the development of infrastructure, especially in the transportation sector.

- Human capital: the level of education is expected to have a positive impact on the location decision especially in non-manufacturing sectors as it enhance the quality of human capital. The education level if measured by the number of students enrolled in senior middle schools as a percentage of population (EDU). 
We are using the $\log$ of all variables, except for the dummy $\mathrm{C}$ as well as the Distance variable.

\section{Results}

Results of the conditional logistic regression are given in Table 1. The agglomeration effect and the level of economic activity appear to have the largest impact on location choice by Japanese investors in manufacturing as well as nonmanufacturing sectors. For both sectors the two variables are strongly significant, holding the highest positive coefficient (especially for non-manufacturing activities).

\section{Table 1 : Conditional (fixed-effects) logistic regression}

As expected, high wage level strongly discourages Japanese investors in the manufacturing sector. This shows that Japanese affiliates activities in labor intensive sector took advantage of China's cheap labor. This finding is corroborated by the significant negative impact of education level in the same sector. In nonmanufacturing activities, wage level also holds a negative coefficient, but the variable is less significant. Education level is positive but not significant. It can be suggested that in the later sector, investors give more importance to qualified labor force.

The amount of Japanese ODA attributed to each province is strongly significant in the two sectors and confirms that aid has a spillover effect on the location decision of Japanese investors. This positive effect is shown to be slightly more important for non-manufacturing activities. Indeed, ODA projects have been 
concentrated mainly on economic infrastructures, considered as high priority by the Chinese government itself, in order to resolve serious bottlenecks in the economy. This is also proved by the impact of infrastructure indicator such as telecommunication facilities. This had an important 'spillover effect' on promoting Japanese investors activities. As far as the loan component of ODA is concerned (which constitutes the bulk of Japanese aid to China), this finding confirms the idea that the incentive for future private investment and technology transfer not only allowed a high rate of reimbursement of loan aid, but that the duty to reimburse constitutes an indicator of solvability well perceived by private investors (Teboul and Bassino, 1997).

Furthermore, we find that manufacturing activities tend to locate in coastal areas, which offer considerable transport facilities for importing inputs and exporting production output. However, this factor is not significant in the location decision of non-manufacturing activities. Finally, the distance from Japan is proved to have a negative impact on FDI location in both sectors, still favoring north and coastal provinces.

\section{Conclusion}

This econometric analysis allowed us to support the view that Japan's ODA has been quite effective in promoting Japanese FDI in China. Even though other profit-maximizing factors such as the level of economic activity or the agglomeration effect of Japanese firms had a leading role in location decision of Japanese investors, the allocation of aid projects did have a significant positive impact. Japanese ODA programs in China have been mainly allocated to infrastructure projects (especially in transportations), paving the way for future private investment. In Japan, this 
complementary process is generated by both institutional and informal links between the public and private sectors and appears to be substantially beneficial to the recipient country. In a context of growing scarcity of aid, a detailed analysis of this effective framework of development cooperation could be an enriching and useful exercise.

\section{Aknowledgements}

I would like to express all my gratitude to professor Kyoji Fukao for his precious advices and comments regarding this study and to professor Ding Jianping for generous provision of Chinese statistics.

\section{References}

- BELBERDOS R. \& CARREE M. (2002), The Location of Japanese Investments in China : Agglomeration Effects, Keiretsu, and Firm Heterogeneity, Journal of the Japanese and International Economies, June 16(2), pp. 194-211.

- Economic Planning Agency (2000), Kaihatsu Tojou Koku no Keizai Hatten to Enshakkan no Yakuwari ni kansuru Chousa [Rapport on the Economic Development of Developing Countries and the Role of Yen Loan], Zaidan Houjin Kokumin Keizai Kenkyu Kyokai, (Research Institute on the National Economy), Tokyo.

- ENSIGN M.M. (1992), Doing Good or Doing Well ? Japan's Foreign Aid Program, Colombia University Press, New York. 
- FUKAO K. (1996), Kokunaika Kaigaika - Wagakuni Seizogyo no Richi Sentaku ni kansuru Jisho Bunseki [At Home or Abroad ? Empirical Analysis regarding Location Selection by Japanese Companies], Keizai Kenkyu, Vol. 47, № 1 .

- FUKAO K. \& TEI L. (1996), Chokusetsu Toushi Sakikoku no Kettei Youin ni tsuite [Concerning the Decision Factors of Direct Investor Countries], Financial Review, Finance Research Center of MOF, Tokyo.

- FUKAO K. \& YUE X. (1997), Denki maker no richi sentaku [The Location Selection of Japanese Electronic Firms], Mita Gakkai Zasshi, Vol.90 N².

- HANABUSA M. (1991), A Japanese Perspective on Aid and Development, in Yen for Development, edited by Islam S. Council on Foreign Relations press, New York.

- HEAD K, RIES J. and SWENSON D. (1995), Agglomeration benefits and location choices: evidence from Japanese manufacturing investments in the US, Journal of International Economics, 38, 223-47.

- ICHIKAWA H. (1991), Japanese Direct Investment and Development Finance, in Yen for Development, edited by Islam S. Council on Foreign Relations press, New York.

- International Development Center of Japan (1997), The Role of Japan's ODA for Asian Countries.

- INUI T. (2000) Characteristics of Overseas Activities of Japanese Companies in Developing Countries, Symposium for Aid Effectiveness, November $20^{\text {th }} 2000$, Economic Planning Agency, Tokyo.

- JICA (1999), The Second Country Study for Japan's Official Development Assistance to the People's Republic of China.

- JBIC (2001), JBIC ODA Loans to the People's Republic of China. 
- KATADA S.N. (1999), Why did Japan suspend foreign aid to China ? Japan's foreign aid decision-making and sources of aid sanction, Paper for ISA.

- KAWAI M. \& TAKAGI S. (2001), Japan's Official Development Assistance : Recent Issues and Future Directions, Mimeographed (June), Institute of Social Science, University of Tokyo.

- KOHAMA H. (1998), ODA no Keizaigaku, Nihon Hyouronsha.

- KOPPEL B.M. \& ORR R..M. (1993), Japan's Foreign Aid : Power and Policy in a New Era, edited by Bruce M. Koppel and Robert M. Orr Jr., Westview Press, Boulder.

- LIPSEY R.E. (1999), The Location and Characteristics of US Affiliates in Asia, NBER Working Paper Series, Working paper 6876, January 1999.

- McFADDEN D. (1973), Conditional Logit Analysis of Qualitative Choice Behavior, in P. Zaremka ed., Frontiers in Econometrics, Academic Press, New York.

- NAKAMURA O., SHISHIDO S., MINATO N., KUROKAWA M., KAWAKAMI A. (2001), Chugoku to Indonesia ni taisuru wagakuni no ODA no hikaku kenkyu : ODA-FDI wo fukumu tabumongata modelu bunseki [A comparative analysis of Japan's ODA to China and Indonesia : a multi-sector model analysis of ODA and FDI], The Japan Society for International Development, 2001 National General Meeting.

- NISHIGAKI A. \& SHIMOMURA Y. (1999), The Economics of Development Assistance : Japan's ODA in a Symbiotic World, LTCB International Library Foundation.

- OCHI S. (1991), Japanese Banks and Third World Debt, in Yen for Development, edited by Islam S. Council on Foreign Relations press, New York. 
- OKAMOTO Y. \& YOKOTA K. (1992), Nihon no Enjo Seisaku no Suuryou Bunseki -Nikoku Enjo no Kunibetsu Haibun Hiritsu no Kettei , [Empirical analysis of Japan's Aid Policy - Determinants of the Country Allocation of Japan's bilateral ODA], Kokusai Kaihatsu Kenkyuu, Vol.1, ํ⒉

- QUANSHENG Z. (1993), Japan's Aid Diplomacy with China, in Japan's Foreign Aid : Power and Policy in a New Era, edited by Bruce M. Koppel and Robert M. Orr Jr., Westview Press, Boulder.

- RIX A. (1996), Japan's Emergence as a Foreign-Aid Superpower, in Foreign Aid Toward the Millennium, edited by Steven W. Hook, Lynne Rienner.

- SÖDERBERG M. (1996), The Business of Japanese Foreign Aid : Five Case Studies from Asia, Routledge.

- STORY G. (1987), Japan's Official Development Assitance to China : a survey, Pacific Economic Paper, $\mathrm{N}^{\circ}$ 150, Australia-Japan Research Center.

- TEBOUL R., BASSINO J.P., (1996), La contribution de l'aide publique et des investissements directs Japonais à la croissance des pays en développement de l'Asie de l'Est, Seminar Stratégie de croissance et marchés émergents organised by the 'Caisse des Dépôts et Consignations', the Development Center OECD, the CEFI, the CEPII, the 'Direction des Relations Economiques Extérieures' (DREE), the 'Ministère de l'Economie et des Finances' and the Revue Economique, Ho Chi Minh Ville, November 1996.

- TERANISHI O. (1983), Waga Kuni no Seifu Kaihatsu Enjou Seisaku ni tsuite, [On the Japanese Foreign Aid Policy], Discussion Paper Series, $\mathrm{N}^{\circ} 83$, The Institute of Economic Research, Hitotsubashi University, Tokyo. 
- URATA S. \& KAWAI H. (1998), The Determinants of the Location of Foreign Direct Investment by Japanese Small and Medium-Sized Enterprises, The EPA Economic Research Industry, Tokyo.

- YOSHIOKA S., MORO K. \& SAWADA M. (1998), ODA and Asian FDI Inflow: An Empirical Analysis in Selected Southeast Asian Countries, The EPA Economic Research Industry, Tokyo.

- ZHANG G. (1996), Rail aid to China, in The Business of Japanese Foreign Aid: Five Case Studies from Asia, Routledge. 


\section{List of Tables}

Table 1 : Conditional (fixed-effects) logistic regression

\begin{tabular}{c|c|c}
\hline Variable & Manufacture & Non-Manufacture \\
\hline \multirow{2}{*}{ C } & $0.297 * * *$ & -0.045 \\
& $(3.245)$ & $(-0.275)$ \\
LJAc & $0.623 * * *$ & $0.605 * * *$ \\
LODAc & $(9.552)$ & $(6.872)$ \\
& $0.129 * * *$ & $0.189 * * *$ \\
LGDPc & $(3.880)$ & $(2.715)$ \\
& $0.638 * * *$ & $1.220 * * *$ \\
LWAGE & $(4.514)$ & $(4.829)$ \\
& $-0.679 * * *$ & $-0.651 * *$ \\
LEDU & $(-3.617)$ & $(-1.923)$ \\
& $-0.635 * *$ & 0.39 \\
DIST & $(2.218)$ & $(0.745)$ \\
& $-0.174 * * *$ & $-0.299 * *$ \\
LTEg likelihood & $(-2.599)$ & $(-2.160)$ \\
& $0.285 * * *$ & $0.399 * * *$ \\
& $(3.823)$ & $(3.737)$ \\
& -4147.6929 & -1290.6864 \\
\hline$* * 19$ & \\
\hline
\end{tabular}

$*, * *, * * *$ mark the results which are respectively $10 \%, 5 \%, 1 \%$ significant. 


\section{Footnotes}

1 - ODA Annual Report, Ministry of Foreign Affairs, various years.

2 - See for example Teranishi (1983).

3 - The International Development Center of Japan (1997), Yosioka, Moro \& Sawada (1998), Inui (2000) and more recently Nakamura et al (2001).

4 - Other examples can be found in Fukao (1996), Fukao and Tei (1996). 